\title{
TENTH ANNUAL LIST OF PAPERS
}

READ BEFORE THE AMERICAN MATHEMATICAL SOCIETY AND SUBSEQUENTLY PUBLISHED, INCLUDING REFERENCES

TO THE PLACES OF THEIR PUBLICATION.

Blake, E. M. Two Plane Movements Generating Quartic Scrolls. Read Dec. 28, 1899. Transactions of the American Mathematical Society, vol. 1, No. 4, pp. 421-429; Oct., 1900.

Blichfeld , H. F. Note on the Functions of the Form $f(x) \equiv \phi(x)$ $+a_{1} x^{n-1}+a_{2} x^{n-2}+\cdots+a_{n}$ which in a given Interval Differ the least Possible from Zero. Read (Chicago) A pril 14, 1900. Transactions of the American Mathematical Society, vol. 2, No. 1, pp. 100-102 ; Jan., 1901.

- A new Determination of the Primitive Continuous Groups in Two Variables. Read April 27, 1901. Transactions of the American Mathematical Society, vol. 2, No. 3, pp. 249-258; July, 1901.

Bôcher, M. Application of a Method of D'Alembert to the Proof of Sturm's Theorems of Comparison. Read June 29, 1900. Transactions of the American Mathematical Society, vol. 1, No. 4, pp. 414-420; Oct , 1900.

- On Linear Dependence of Functions of One Variable. Read Oct. 27, 1900. Bulletin of the American Mathematical Society, vol. 7, No. 3, pp. 120-121; Dec., 1900.

- Certain Cases in which the Vanishing of the Wronskian is a Sufficient Condition for Iinear Dependence. Read Dec. 28, 1900. Transactions of the American Mathematical Society, vol. 2, No. 2, pp. 139-149; April, 1901.

- An Elementary Proof of a Theorem of Sturm. Read Feb. 23, 1901. Transactions of the American Mathematical Society, vol. 2, No. 2, pp. 150-151; April, 1901.

- Green's Functions in Space of One Dimension. Read Feb. 23, 1901. Bulletin of the American Mathematical Society, vol. 7, No. 7, pp. 297299 ; April, 1901.

- Non-Oscillatory Linear Differential Equations of the Second Order. Read Feb. 23, 1901. Bulletin of the American Mathematical Society, vol. 7, No. 8, pp. 333-340; May, 1901.

CAJoRI, F. Divergent and Conditionally Convergent Series whose Product is Absolutely Convergent. Read April 28, 1900. Transactions of the American Mathematical Society, vol. 2, No. 1, pp. 25-36 ; Jan., 1901 .

Dickson, L. E. The Cyclic Subgroup of the Simple Group of Linear Fractional Substitutions of Determinant Unity in two Non-Homogeneous Variables with Coefficients in an Arbitrary Galois Field. Read (Chicago) Dec. 28, 1899. American Journal of Mathematics, vol. 22, No. 3, pp. 231-252; July, 1900.

- Determination of an Abstract Simple Group of Order $2^{7}$. $3^{6} .5 .7$ Holoedrically Isomorphic with a certain Orthogonal Group, and 
with a certain Hyperabelian Group. Read (Chicago) April 14, 1900. Transactions of the American Mathematical Society, vol. 1, No. 3, pp. 353-370 ; July, 1900.

- Canonical Forms of Quaternary Abelian Substitutions in an Arbitrary Galois Field. Read (Chicago) Dec. 28, 1900. Transactions of the American Mathematical Society, vol. 2, No. 2, pp. 103-138 ; April, 1901.

- Concerning Real and Complex Continuous Groups. Read Feb. 23, 1901. Bulletin of the American Mathematical Society, vol. 7, No. 8, pp. 340-350 ; May, 1901.

Eisenhart, L. P. A Demonstration of the Impossibility of a Triply Asymptotic System of Surfaces. Read Dec. 28, 1900. Bulletin of the American Mathematical Society, vol. 7, No. 4, pp. 184-186 ; Jan., 1901.

- Possible Triply Asymptotic Systems of Surfaces. Read Feb. 23, 1901. Bulletin of the American Mathematical Society, vol. 7, No. 7, pp. 303-305; April, 1901.

- Surfaces whose First and Second Fundamental Forms are the Second and First Respectively of Another Surface. Read Feb. 23, 1901. Bulletin of the American Mathematical Society, vol. 7, No. 10, pp. 417423 ; July, 1901.

Fields, J. C. On the Reduction of the General Abelian Integral. Read Aug. 16, 1897. Transactions of the American Mathematical Society, vol. 2, No. 1, pp. 49-86 ; Jan., 1901.

ForD, W. B. Dini's Method of Showing the Convergence of Fourier's Series and Other Allied Developments. Read Dec. 28, 1900. Bul. letin of the American Mathematical society, vol. 7, No. 5, pp. 227-230; Feb., 1901 .

GALE, A. S. Wiener's Theory of Displacements, with an Application to the Proof of Four Theorems of Chasles. Read April 28, 1900. Annals of Mathematics, 2d series, vol. 2, No. 1, pp. 1-7; Oct., 1900.

Gordan, P. Die Hesse'sche und die Cayley'sche Curve. Read June 28, 1900. Transactions of the American Mathematiaal Society, vol. 1, No. 4, pp. 402-413 ; Oct., 1900.

HathawAy, A. S. Pure Mathematics for Engineering Students. Read (Chicago) Dec. 28, 1900. Bulletin of the American Mathematical Society, vol. 7, No. 6, pp. 266-271; March, 1901.

HAwKes, H. E. Note on Hamilton's Determination of Irrational Numbers. Read Feb. 23, 1901. Bulletin of the Aiierican Mathematical Society, vol. 7, No. 7, pp. 306-307 ; April, 1901.

Hilbkrt, D. Ueber Flächen von constanter Gauss'scher Krümmung, Read Oct. 27, 1900. Transactions of the American Mathematical Society. vol. 2, No. 1, pp. 87-99; Jan., 1901.

Hutchinson, J. I. On Certain Relations Among the Theta Constants. Read Dec. 28, 1899. Transactions of the American Mathematical Society, vol. 1, No. 4, pp. 391-394; Oct., 1900.

On some Birational Transformations of the Kummer Surface into Itself. Read Dec. 28, 1900. Bulletin of the American Mathematical Society, vol. 7, No. 5, pp. 211-217 ; Feb., 1901. 
Hyde, E. W. On a Surface of the Sixth Order Which is Touched by the Axes of all Screws Reciprocal to Three Given Screws. Read Apri1 27, 1901. Annals of Mathematics, 2d ser., vol. 2, No. 4, pp. 179-188; July, 1901.

KASNER, E. The Invariant Theory of the Inversion Group : Geometry upon a Quadric Surface. Read (Columbus) Aug. 25, 1899. Transactions of the American Mathematical Society, vol. 1 , No. 4, pp. 430498 ; Oct., 1900.

- On the Algebraic Potential Curves. Read Feb. 23, 1901. Bulletin of the American Mathematical Society, vol. 7, No. 9, pp. 392-399; June, 1901.

Keyser, C. J. Theorems Concerning Positive Definitions of Finite Assemblage and Infinite Assemblage. Read Dec. 28, 1900. Bulletin of the American Mathematical Society, vol. 7, No. 5, pp. 218-226 ; Feb., 1901.

Krause, M. Ueber Systeme von Differentialgleichungen denen vierfach periodische Functionen Genüge leisten. Read (Chicago) April 14, 1900. Transactions of the American Mathematical Society, vol. 1, No. 3, pp. 287-292; July, 1900.

Loun, F. H. Sundry Metric Theorems Concerning $n$ Lines in a Plane. Read April 28, 1900 Transactions of the American Mathematical Society, vol. 1, No. 3, pp. 323-338; July, 1900.

Lovetr, E. O. The Condition that a Linear Total Differential Equation be Integral. Read April 28, 1900 . Annals of Mathematics, 2d series. vol. 1 , No. 4, pp. 175-176; July, 1900. Also Report of the British Association for the Advancement of Science, 1899, p. 652.

- Note on Geometry of Four Dimensions. Read April 28, 1900. Bulletin of the American Mathematical Society, vol. 7 , No. 2 , pp. 88100 ; Nov., 1900.

- Construction of the Geometry of Euclidean $n$-Dimensional Space by the Theory of Continuous Groups. Read Oct. 27, 1900. American Journal of Mathematics, vol. 23, No. 1, pp. 57-67; Jan., 1901.

McClintock, E. A Simplified Solution of the Cubic. Read Dec. 28, 1900. Annals of Mathematics, 2d series, vol. 2, No. 3, pp. 151-152; April, 1901.

Martin, E. N. On the Imprimitive Substitution Groups of Degree Fifteen and the Primitive Substitution Groups of Degree Eighteen. Read Aug. 25, 1899 . American Journal of Mathematics, vol. 23, No. 3, pp. 259-286 ; July, 1901.

Mertens, F. Zur linearen Transformation der $\vartheta$-Reihen. Read (Chicago) Apr. 6, 1901. Transactions of the American Mathematical Society, vol. 2, No. 3, pp. 331-342; July, 1901.

Miller, G. A. On the Groups which have the Same Group of Isomorphisms. Read Dec. 28, 1899 . Transactions of the American Mathematical Society, vol. 1, No. 4, pp. 395-401 ; Oct., 1901.

- On Holomorphisms and Primitive Roots. Read Feb. 23, 1901. Bulletin of the American Mathematical Society, vol. 7, No. 8, pp. 350354 ; May, 1901.

- On the Groups Generated by Two Operators. Read Apr. 27, 1901. Bulletin of the American Mathematical Society, vol. 7, No. 10, pp. 424426 ; July, 1901. 
Determination of all the Groups of Order $p^{m}$ which Contain the Abelian Group of Type $(m-2,1), p$ being any Prime. Read (Chicago) Apr. 6, 1901. Transactions of the American Mathematical Society, vol. 2, No. 3, pp. 259-272 ; July, 1901.

Moore, E. H. A Fundamental Remark Concerning Determinantal Notations with the Evaluation of an Important Determinant of Special Form. Read (Chicago) April 14, 1900. Annals of Mathematics, 2d series, vol. 1, pp 177-188; July, 1900.

- The Cross-Ratio Group of $n$ ! Cremona Transformations of Order $n-3$ in Flat Space of $n-3$ Dimensions. Read (Buffalo) 1896. American Journal of Mathematics, vol. 22, No. 3, pp. 279-291 ; July, 1900.

A Simple Proof of the Fundamental Cauchy-Goursat Theorem. Read June 29, 1900. Transartions of the American Mathematical Society, vol. 1, No. 4, pp. 499-506 ; Oct., 1900.

- Concerning Harnack's Theory of Improper Definite Integrals. Read (Chicago) Dec. 27, 1900. Transactions of the American Mathematical Society, vol. 2, No. 3, pp. 295-330 ; July, 1901.

Moritz, R. E. Extension of Hurwitz's Proof for the Transcendence of $e$ to the Transcendence of $\pi$. Read (Chicago) April 14, 1900. Annals of Mathematics, 2d series, vol. 2, No. 2, pp. 57-59; Jan., 1901.

MorLey, F. The Value of $\int_{0}^{\pi / 2}(\log 2 \cos \phi)^{m} \phi^{n} d \phi$. Read April 29, 1899. Bulletin of the American Mathematical Society, vol. 7, No. 9, pp. 390392 ; June, 1901.

Newson, H. B. Indirect Circular Transformations and Mixed Groups. Read Feb. 23, 1901. Bulletin of the American Mathematical Society, vol. 7, No. 6, pp. 259-266; March, 1901.

OsGood, W. F. On the Existence of the Green's Function for the most General Simply Connected Plane Region. Read June 29, 1900. Transactions of the American Mathematical Society, vol. 1, No. 3, pp. 310-314; July, 1900.

- On the Existence of a Minimum of the Integral $\int_{x_{0}}^{x_{1}} F\left(x, y, y^{\prime}\right) d x$ when $x_{0}$ and $x_{1}$ are Conjugate Points, and the Geodesics on an Ellipsoid of Revolution : a Revision of a Theorem of Kneser's. Read Dec. 28, 1900. Transactions of the American Mathematical Society, vol. 2 , No. 2, pp. 166-182; April, 1901.

On a Fundamental Property of a Minimum in the Calculus of Variations and the Proof of a Theorem of Weierstrass. Read April 27, 1901. Transactions of the American Mathematical Society, vol. 2, No. 3, pp. 273-294; July, 1901.

Perrce, G. A Curious Approximate Construction for $\pi$. Read Apr. 27, 1901. Bulletin of the American Mathematical Society, vol. 7, No. 10, pp. 426-427; July, 1901.

Pell, A. "D" Lines on Quadrics. Read (Columbus) Aug. 25, 1899. Transactions of the American Mathematical Society, vol. 1, No. 3, pp. 315-322; July, 1900.

Pierpont, J. P. Galois' Theory of Algebraic Equations. Part II. Irrational Resolvents. Read Sept., 1896. Annals of Mathematics, 2d series, vol. 2, No. 1, pp. 22-56; Oct , 1900. 
Ponter, M. B. Sets of Coincidence Points on the Non-Singular Cubics of a Syzygetic Sheaf. Read June 29, 1900, under a different title. Transactions of the American Mathematical Society, vol. 2, No. 1, pp. 37-42 ; Jan., 1901.

PupIN, M. I. Wave Propagation Over Non-Uniform Electrical Conductors. Read Dec. 28, 1899. Transactions of the American Mathematical Society, vol. 1, No. 3, pp. 259-286 ; July, 1900.

REID, L. W. A Table of Class Numbers for Cubic Number Bodies, with the Method of their Calculation. Read Feb. 24, 1900. American Journal of Mathematics, vol. 23, No. 1, pp. 68-84 ; Jan., 1901.

RoE, E. D. On a Formula of Interpolation. Read Dec. 28, 1900. American Mathematical Monthly, vol. 8, No. 1, pp. 1-9 ; Jan., 1901.

Slaught, H. E. The Cross-Ratio Group of 120 Quadratic Cremona Transformations of the Plane. Part Second : Complete Form-System of Invariants. Read Dec. 28, 1900. American Journal of Mathematics, vol. 23, No. 2, pp. 99-138; April, 1901.

Smith, P. F. On Surfaces Enveloped by Spheres Belonging to a Linear Spherical Complex. Read June 29, 1900, under a different title. Transactions of the American Mathematical Society, vol. 1, No. 4, pp. 371-390 ; Oct., 1900.

Geometry within a Linear Spherical Complex. Read Oct. 27, 1900. Transactions of the American Mathematical Society, vol. 2, No. 3, pp. 234-248; July, 1901.

SNYDER, V. On Some Invariant Scrolls in Collineations which Leave a Group of Five Points Invariant. Read April 28, 1900. American Journal of Mathematics, vol. 22, No. 3, pp. 253-258 ; July, 1900.

- On a Special Form of Annular Surfaces. Read June 27, 1900. American Journal of Mathematics, vol. 23, No. 2, pp. 166-172; A pril, 1901.

- On a System of Plane Curves Having Factorable Parallels. Read Dec. 28, 1900. Bulletin of the American Mathematical Society, vol. 7, No. 7, pp. 299-302 ; April, 1901.

STECKer, H. F. On the Determination of Surfaces Capable of Conformal Representation upon the Plane in such a Manner that Geodetic Lines are Represented by Algebraic Curves. Read Feb. 23, 1901. Transactions of the American Mathematical Society, vol. 2, No. 2, pp. 152165 ; April, 1901.

StringhaM, I. On the Geometry of Planes in a Parabolic Space of Four Dimensions. Read (Chicago) Dec. 27, 1900. Transactions of the American Mathematical Society, vol. 2, No. 2, pp. 183-214 ; A pril, 1901.

Strong, W. M. Note on Non-Quaternion Number Systems. Read (Columbus) Aug. 25, 1899. Transactions of the American Mathematical Society, vol. 2, No.1, pp. 43-48 ; Jan., 1901.

VAN VLECK, E. B. On Linear Criteria for the Determination of the Radius of Convergence of a Power Series. Read Feb. 24, 1900. Transactions of the American Mathematical society, vol. 1, No. 3, pp. 293-309 ; July, 1900.

On the Convergence of Continued Fractions with Complex Elements. Read Feb. 23, 1901 and April 27, 1901. Transactions of the American Mathematical Society, vol. 2, No. 3, pp. 215-233 ; July, 1901. 
Westlund, J. Note on Multiply Perfect Numbers. Read Apr. 6, 1901. Annals of Mathematics, 2d series, vol. 2, No. 4, pp. 172-174; July, 1901.

WILCZYNSKI, E. J. An Application of Group Theory to Hydrodynamics. Read (Chicago) Dec. 29, 1899. Transactions of the American Mathematical Society, vol. 1, No. 3, pp. 339-352; July, 1900.

- Transformations of Systems of Linear Differential Equations. Read April 28, 1900. American Journal of Mathematics, vol. 23, No. 1, pp. 29-36; Jan., 1901.

Wood, R. G. The Collineations of Space which Transform a Non-Degenerate Quadric Surface into Itself. Read Dec. 28, 1900. Annals of Mathematics, 2d series, vol. 2, No. 4, pp. 161-171 ; July, 1901. 